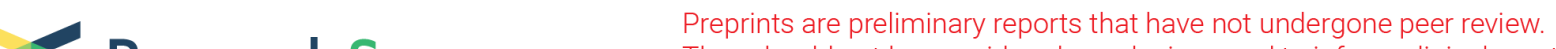 $\begin{array}{ll}\text { Research Square } & \text { They should not be considered conclusive, used to inform clinical practice, } \\ \text { or referenced by the media as validated information. }\end{array}$
}

\section{Development of white-grain pre-harvest sprouting tolerant and pyramided protein-rich leaf rust resistant wheats using molecular breeding}

\section{Tinku Gautam}

Chaudhary Charan Singh University

\section{Kuldeep Kumar}

Chaudhary Charan Singh University

\section{Priyanka Agarwal}

IARI: Indian Agricultural Research Institute

\section{Sandhya Tyagi}

IARI: Indian Agricultural Research Institute

\section{Vandana Jaiswal}

CSIR-IHBT: Institute of Himalayan Bioresource Technology CSIR

\section{Vijay Gahlaut}

CSIR-IHBT: Institute of Himalayan Bioresource Technology CSIR

\section{Sachin Kumar}

Chaudhary Charan Singh University

\section{Pramod Prasad}

Directorate of Wheat Research: ICAR - Indian Institute of Wheat and Barley Research

\section{Parveen Chhuneja}

Punjab Agricultural University

Harindra Singh Balyan

Chaudhary Charan Singh University

Pushpendra Kumar Gupta ( $\sim$ pkgupta36@gmail.com )

Ch. Charan Singh University https://orcid.org/0000-0001-6374-9148

\section{Research Article}

Keywords: Marker-assisted selection (MAS), pyramiding, pre-harvest sprouting tolerance, grain protein content, rust resistance

Posted Date: April 20th, 2021

DOI: https://doi.org/10.21203/rs.3.rs-284315/v1 
License: (c) (i) This work is licensed under a Creative Commons Attribution 4.0 International License. Read Full License 


\section{Abstract}

The present study was undertaken for developing pre-harvest sprouting tolerant (PHST) wheat genotypes using marker-assisted backcross breeding (MABB). A major QTL for PHST was introgressed into an elite Indian wheat cv. Lok1 that is PHS susceptible. These PHST lines were also pyramided with one gene each for high grain protein content (Gpc-B1) and leaf rust resistance (Lr24). For introgression of PHST QTL, initially Lok1 was separately crossed with each of the two donors (PHS tolerant white-grained AUS1408 and CN19055). Backcrossing in each generation was followed by foreground and background selections using SSR markers. In advanced lines, KASP assay was also carried out for the candidate gene TaMKK3-A underlying the PHST QTL. The MAS derived lines homozygous for PHST QTL were screened for PHS using simulated rain chambers resulting in the selection of 10 PHST lines. For pyramiding of three QTL/genes (PHST QTL, Gpc-B1, and $L$ r24), MABB derived $\mathrm{BC}_{4} \mathrm{~F}_{2}$ plants (from the cross Lok1/CN19055) were crossed with a MAS derived $\mathrm{BC}_{2} \mathrm{~F}_{5}$ line [Lok1 $\left.(G p c-B 1+L r 24)\right]$ developed earlier by us in the same background of Lok1. After foreground MAS followed by PHS screening, four advanced lines carrying all the three QTL/genes in homozygous condition were selected. These lines exhibited high level of PHST (PHS score 2-3) associated with significant improvement in GPC with no yield penalty and resistance against leaf rust under artificial epiphytotic conditions.

\section{Introduction}

Pre-harvest sprouting (PHS) refers to precocious germination of grains within physiologically mature spikes on prolonged rains before harvesting (Groos et al. 2002). Seed dormancy (SD) has also been used as a surrogate trait for PHS tolerance (PHST) because PHST is known to depend on seed dormancy and the two traits exhibit high correlation (Li et al. 2004). PHS leads to yield losses and significant reduction in grain quality due to activation of enzymes like lipases, amylases and proteases in developing grains leading to degradation of lipids, starch, and proteins (Andreoli et al. 2006; Simsek et al. 2014). PHS also leads to reduction in market value of wheat grain, by $50 \%$, ultimately resulting in a global estimated loss of US \$1 billion annually (Ali et al. 2019). PHS problem is common in all major wheat growing areas of the world, including Canada, Europe, Australia, China, USA, Japan, and also some parts of India (Rajjou et al. 2012; Zhou et al. 2018).

PHS is a complex trait controlled by a large number of genes and is influenced by the environment. PHST is often associated with red grain color (DePauw and McCaig, 1983; Groos et al. 2002; Fofana et al. 2009), so that grain color and seed dormancy both are used as a markers for PHST (Flintham, 2000; Mares et al. 2005). However, PHS tolerant white grain wheat genotypes are also known, which include AUS1408 (Mares, 1987) and CN19055 (Hucl and Matus-Cadiz, 2002). Following parameters are generally used for estimating the level of PHST: PHS index, falling number, germination index and alpha amylase activity (Nörnberg et al. 2015; Shorinola et al. 2016). Among cereals, in wheat alone, 50 QTL interval mapping studies involving $~ 40$ mapping populations have already been conducted leading to identification of as many as $>250$ QTLs for PHST, which also included hexaploid synthetic wheats, tetraploid durum wheats and diploid einkorn wheats (see review by Gupta et al. 2020). Relatively, more 
important QTL for PHST and seed dormancy are known to be carried by chromosomes 3A, 3B, 3D, and 4A, although all the 21 chromosomes carry QTLs for this trait (see Gupta et al. 2020). MetaQTLs have also been identified for PHST in wheat (Tyagi and Gupta, 2012). Genome wide association studies (GWAS) have also been conducted for PHST and related traits leading to identification of 250 MTAs (for details see review by Gupta et al. 2020). A number of these MTAs were located in genomic regions carrying QTLs earlier identified through interval mapping. Among known QTLs, 30 QTLs have also been shown to be stable over environments; these have been considered potentially useful for improvement of PHST in wheat. A major QTL on chromosome 3A, associated with red grain color (QPhs.ccsu-3A. 1; Kulwal et al. 2005) and another QTL Phs-A1, located on chromosome arm 4AL are considered to be relatively more important for breeding (Mori et al. 2005; Mares et al. 2005; Liu et al. 2008). Phs-A1 has also been cloned and characterized (Barrero et al. 2015; Shorinola et al. 2017). Two genes, namely PM19-A1 and PM19-A2 (Plasma Membrane 19 genes) were proposed as the main candidates for the QTL Phs-A1 (Barrero et al. 2015), although on the basis of comparative analysis of synteny, as many as 10 orthologous genes were proposed as candidate genes. The QTL Phs-A1 also overlaps the gene TaMKK3$A$ for seed dormancy (Torada et al. 2016). Recently, markers for QTL Phs-A1 and the gene TaMKK3-A, were also developed (Shorinola et al. 2017). It was also shown that TaMKK3-A alleles are diagnostic for sprouting resistance in parents of mapping populations used for identification of the QTL Phs-A1.

It has been recognized that initially during green revolution, improvement in yield was a major concern, and that during the last three decades, GPC has also attracted the attention of wheat breeders to address the problem of nutritional security in developing countries (Joshi et al. 2007). Therefore, among important traits for wheat breeders, grain protein content (GPC) and resistance to three rusts including leaf rust are also important. Although, several loci affecting GPC have been identified in wheat, the most important gene affecting GPC is Gpc-B1, which was initially identified in wild emmer wheat (Triticum turgidum L. ssp. dicoccoides) and was subsequently cloned following map-based cloning strategy (Uauy et al. 2006). Gpc-B1 encodes a NAC-domain transcription factor and is located on the short arm of chromosome 6B, tightly linked with genes for accelerated senescence and high grain Fe/Zn concentration (Distelfeld et al. 2007; reviewed in Tabbita et al. 2017).

Suitable RFLP, CAPS, and SSR markers are available for Gpc-B1 (Mesfin et al. 1999; Khan et al. 2000; Olmos et al. 2003; Distelfeld et al. 2006; Uauy et al. 2006). During the last decade, Gpc-B1 has been extensively deployed in durum and common wheats for improvement of GPC, so that most modern wheat varieties all over the world now carry Gpc-B1 (Uauy et al. 2006; Hagenblad et al. 2012; Brevis and Dubcovsky 2010; Kumar et al. 2011; Balyan et al. 2013; Vishwakarma et al. 2014; Vishwakarma et al. 2016; Bokore et al. 2019; Gautam et al. 2020). However, it has been a challenge to develop wheat varieties with high GPC without yield penalty due to several factors including the following: negative correlation between the grain yield and GPC (rage of correlation $=-0.30$ and -0.60 ), large environmental effects, genotype-by-environment interactions, and a complex genetic system governing GPC (Simmonds, 1995; DePauw et al. 2007; Klindworth et al. 2009; Brevis and Dubcovsky 2010). The backcross-derived lines containing $G p c-B 1$ have also been found to have reduced kernel weight and earlier senescence, both adversely affecting grain yield (Sherman et al. 2008). 
In our own research extending over two decades, we also observed that PHS tolerant wheats improved for GPC are often susceptible to leaf rust, which causes significant losses ( 7-30\%) in wheat yield worldwide (Bolton et al. 2008). Leaf rust resistance genes have been regularly discovered, so that $\sim 80 \mathrm{Lr}$ genes are now known in wheat (Mclntosh et al. 2017). Among these Lr genes, $L r 24$ is an important gene, which has been widely deployed in wheat cultivars because it provides resistance at all developmental stages. The gene $L r 24$ is also linked with $S r 24$ so that $L r 24$ has become a gene of choice in wheat breeding programmes (Bhardwaj et al. 2019).

In view of the above, the development of PHS tolerant, protein-enriched leaf rust resistant wheats using molecular breeding became an important goal in our laboratory, since markers for all the three targeted traits are available. This goal has now been successfully achieved using wheat cv. Lok1, which has been widely grown in central India. The results of this study, extending almost a decade, are presented in this communication.

\section{Materials And Method}

\section{Material}

Plant materials used in the present study included the following: (i) an Indian wheat cv. Lok1, (ii) two wheat genotypes, namely AUS1408 and CN19055, each carrying a major PHST QTL located on chromosome arm 4AL (Mares et al., 2005; Ogbonnaya et al. 2008); these two genotypes were used as two independent donors; (iii) a MAS derived line in the background of cv. Lok1 containing Gpc-B1+Lr24, where $G p c-B 1$ is a locus for high grain protein content, which is in close linkage with a stripe rust resistance gene (Yr36); this improved line was used as a donor for pyramiding of genes for GPC and resistance to leaf rust and on to PHST locus carried by the improved $\mathrm{BC}_{4} \mathrm{~F}_{2}$ plants. The Lok1 cultivar is a high yielding wheat cultivar, released in 1982 for late sown irrigated conditions of central India, where it has been the most preferred wheat variety for cultivation, due to its good bread making quality and superior agronomic performance. The choice of Lok1 as the recipient cultivar was based on the fact that Lok1 was the first among the best 10 varieties, selected from 150 varieties for breeder's seed production across the country for seven consecutive years between 2004 and 2010. At present, Lok1 (63.91 Mt) has third rank after PBW343 (73.42 Mt) and HD2967 (93.38 Mt) in terms of breeder's seed indent for the year 2019-20; it is still grown in an estimated 1 mha wheat area in central India (https://www.lokbharti.org/WheatResearch). Lok1 is also highly resistant to the most virulent rust pathotype Ug-99.

\section{Molecular markers}

The details of the markers linked with QTL/genes introgressed and pyramided during the present study are presented in Table 1. For the recovery of the recurrent parent genome (RPG) in the segregating backcross progenies during background selection, a total of $\sim 130$ polymorphic SSR markers (selected from 453 markers) covering all the 21 chromosomes were used in the following two crosses:

Lok1/AUS1408 and Lok1/CN19055. In each backcross generation, the proportion of the genome from the 
recipient parent was estimated using the following formula; $G=[(X+1 / 2 Y) \times 100] / N$, where, $X$ is the number of markers showing homozygosity for recipient parent alleles; $Y$ is the number of markers showing heterozygosity involving the two parental alleles and $\mathrm{N}$ is the total number of polymorphic markers.

\section{DNA extraction, primer synthesis and PCR analysis}

DNA isolation from 30-40 days old leaves was carried out using the CTAB method following SaghaiMaroof et al. (1984), with some modifications. DNA was quantified on $1 \%$ agarose gel using agarose gel electrophoresis. Primers were synthesized by Eurofins Genomics India Pvt Ltd., Bangaluru, India. Polymerase chain reaction (PCR) was carried out in $20 \mu \mathrm{L}$ reaction mixture containing the following component: $~ 50 \mathrm{ng}$ of template DNA, $1 \mathrm{U}$ Taq polymerase (Sigma-Aldrich, USA), $0.02 \mathrm{mM}$ of each dNTPs (Sigma-Aldrich, USA), $0.2 \mu \mathrm{M}$ primers (forward and reverse), 1X Taq buffer in each case. PCR was performed using Veriti ${ }^{\mathrm{TM}}$ 96-well Thermal Cycler of Applied Biosystem, on following PCR profile: initial denaturation for 4 min at $94^{\circ} \mathrm{C}$, followed by 35 cycles each with $30 \mathrm{sec}$ at $94^{\circ} \mathrm{C}, 30 \mathrm{sec}$ at $50-60^{\circ} \mathrm{C}$ (specific for different primers), $1 \mathrm{~min}$ at $72^{\circ} \mathrm{C}$, and $7 \mathrm{~min}$ at $72^{\circ} \mathrm{C}$ for final extension. Amplification products for marker $\mathrm{SCS}_{71} 3_{719}$ were resolved on $2 \%$ agarose gel and visualized on UV trans-illuminator; products of other markers were resolved on 10\% PAGE gel and visualized by silver staining.

\section{KASP assay}

Kompetitive allele specific PCR (KASP) assay was also conducted to confirm the presence of PHST QTL in the improved lines developed during this study by using the primers earlier developed and used by Shorinola et al (2017). The KASP assay was carried out as described in Bansal et al (2020)

\section{Breeding scheme for introgression and pyramiding of QTL/genes}

Marker assisted backcross breeding (MABB) scheme was followed to transfer the PHST QTL from each of the two donor genotypes (AUS1408 and CN19055) independently into the genetic background of cV. Lok1 (Fig. 1). Recurrent parent Lok1 was used as female and crossed with each donor as male parent. $F_{1}$ plants were used for four generations of backcrossing leading to $B C_{4} F_{1}$. Both foreground and background selections were exercised. The MABB scheme followed in the present study is shown in Fig. 1. Foreground MAS in $\mathrm{BC}_{4} \mathrm{~F}_{2}$ and $\mathrm{BC}_{4} \mathrm{~F}_{3}$ was carried out for selecting plants homozygous for the PHST QTL; these plants were then screened in simulated rain chambers for PHST (more details are provided in the next section). Seed of the selected PHS tolerant plants was multiplied for conducting station yield trials for two consecutive years for evaluation of agronomic traits.

The $\mathrm{BC}_{4} \mathrm{~F}_{2}$ plants (improved for PHST) derived from only one of the two crosses namely Lok1/CN19055 was utilized for pyramiding of genes for high GPC and leaf rust resistance in the background of cv. Lok1. Scheme of the breeding program for pyramiding is also depicted as a part of Fig. 1. For the purpose of pyramiding, the improved PHST plants were crossed as female parent with MAS derived $\mathrm{BC}_{2} \mathrm{~F}_{5}$ line Lok1 $(G p c-B 1+L r 24)$ earlier developed by us in a separate programme. The initial crossing was followed by 
forward breeding for a number of generations using plant to progeny scheme. The $F_{4}$ progenies were screened for rust resistance under artificial epiphytotic conditions (for details see below). The progenies in $F_{4}$ to $F_{6}$ generations were also screened for PHS tolerance under artificial rains (for detail see below). Seed of the selected progenies was multiplied for station yield trials for two consecutive years (for details see below).

\section{Evaluation for PHS and seed dormancy}

For the PHS screening, five randomly selected physiologically mature spikes (when $75 \%$ spikes in a plot turned yellow) were harvested from each selected progenies and immediately kept in specialized simulated rain chambers at room temperature providing artificial rain every $6 \mathrm{~h}$ for seven consecutive days, when data on PHS was scored on a scale of 1-9; score of 1 represented no visible sprouting and a score of 9 represented complete sprouting (Kumar et al. 2010). Mean PHS scores were used for selection of PHS tolerant genotypes.

Data was also recorded on seed dormancy of MAS derived lines following Knox et al (2012). In brief 50 seed were placed in a Petri dish with the crease of each seed facing down to make it easier to observe the germination. Seed with white radicle or plumule protruding with a visible tear in the seed coat were treated as germinated seeds and removed from the plate. Seed counts were recorded daily for 21 days and germination index (GI) was calculated.

\section{Screening of MAS-derived lines for rust resistance}

Screening of the pyramided lines (containing QPhs.dpi.vic.4A.2, Gpc-B1 and Lr24) were carried out against a total of 16 pathotypes of the three rusts reported from different regions of India (for the details of pathotypes used see Table 2). The procedure for screening of rust resistance was described in an earlier study (Gautam et al. 2020). In brief, seedlings were assayed for the infection against each pathotype at 15 days post-inoculation (dpi) following Stakman et al (1962).

\section{Yield trials of MAS-derived lines}

The yield trials included the following 18 lines; (i)10 lines with only PHST QTL, (ii) 4 lines containing QPhs.dpi.vic. $4 A .2+G p c-B 1+L r 24$ and (iii) one recipient and three donor parental genotypes [Lok1, Lok1 (Gpc-B1+Lr24), AUS1408, and CN19055]. Randomized block design with two replications was used at Meerut during 2018-19 and 2019-20 crop seasons. Each line in a replication was evaluated in $6 \mathrm{~m}^{2}$ plots, each having six rows of six meter with a row-to-row distance of $20 \mathrm{~cm}$. Phenotypic data were recorded on the following agronomic and grain quality traits: plant height ( $\mathrm{PH}$ in $\mathrm{cm})$, tillers per meter (TPM), grain number per spike (GNPS), 1000-grain weight (TGW in g), grain yield (GY in g), grain protein content (GPC in \%), iron (Fe in ppm), and zinc (Zn in ppm) contents in grains. The GPC (\%) at $12 \%$ grain moisture content was estimated using FOSS Infratec ${ }^{\text {TM }} 1241$ Grain Analyzer (Denmark).

\section{Statistical analysis}


For statistical analyses, mean values of the two replications for each trait in each trial were used. The descriptive statistics were obtained using Excel. The analysis of variance (ANOVA) for the eight traits was carried out using the SPSS Statistics for Windows, version 16.0 (SPSS Inc., Chicago, III., USA); significance in ANOVA was tested for the following sources of variation: replications, genotypes, environments, genotype-by-environment interactions.

\section{Results And Discussion}

MABB for PHST involving two donors (AUS1408/CN19055): For introgression of PHST QTL separately from each of the two donors, namely AUS1408 and CN19055 into Lok1, two separate MABB programmes were followed. In each case, $F_{1}$ plants were subjected to four backcrosses to recipient parent cv. Lok1 involving foreground and background MAS. For foreground selection of PHST QTL, separate pairs of polymorphic SSR markers were used as follows: (i) Xgwm397 and Xbarc170 in case of AUS1408, and (ii) Xgwm637 and Xgwm894 in case of CN19055. Similarly, for background selection a set 130 polymorphic SSR markers were used in each cross. The amplification profiles of markers used for foreground selection in two crosses are shown in Fig. 2 (for details of SSRs used for background selection see Supplementary Table 1). In $\mathrm{BC}_{4} \mathrm{~F}_{2 / 3}$, homozygous plants were selected and were then subjected to phenotypic selection for PHS in subsequent generations $\left(\mathrm{BC}_{4} \mathrm{~F}_{4}-\mathrm{BC}_{4} \mathrm{~F}_{5}\right)$. KASP assay involving SNPs associated with PHST was also carried out in $\mathrm{BC}_{4} \mathrm{~F}_{6}$ lines to confirm the presence of PHST QTL and the seed dormancy gene TaMKK-3 (Fig. 3). Only 62 of the 115 progenies carried the SNP allele associated with PHST in homozygous condition. It appears that during the foreground selection for PHST QTL, recombination occurred in the large intervals (14.2 cM in case of AUS1402 and $17.8 \mathrm{cM}$ in case of CN19055) between the markers flanking the PHST QTL, leading to the loss of PHST QTL allele in some progenies or to the selection of heterozygous allele at the PHS locus. Therefore, in future, closely linked markers need to be used. Eventually, 10 lines (8 involving AUS1408 and 2 involving CN19055 were selected, each carrying the marker associated with the desired QTL in homozygous condition, associated with $90-96 \%$ RPG, PHS score $<3$ and germination index (G17 at 7 days for testing seed dormancy) ranging from 0.2-0.6.

RPG recovery in the two crosses in the present study did not differ from several earlier wheat breeding programmes where MABB was used for introgression of genes/QTL for biotic and abiotic stresses in wheat (Yadav et al. 2015; Mallick et al. 2015; Vishwakarma et al. 2016; Rai et al. 2018; Randhawa et al. 2019; Todkar et al. 2020: Gautam et al. 2020a). This confirmed the utility of MABB for effective introgression of genes/QTL into the agronomically superior genotypes associated with recovery of recurrent parent genome in a relatively short time as also reported earlier in wheat (Mallick et al. 2015), rice (Divya et al. 2015; Ellur et al. 2016; Ramalingam et al. 2020; Jamaloddin et al. 2020), and maize (Sureshkumar et al. 2014; Kaur R et al. 2020).

\section{Pyramiding of QTL/genes for PHST, high GPC and resistance to leaf rust}


MAS derived $\mathrm{BC}_{4} \mathrm{~F}_{2}$ plants containing the PHST QTL from the donor CN19055 in the background of $\mathrm{cV}$. Lok1 were used for the pyramiding of Gpc-B1, and Lr24, on to QPhs.dpivic.4A.2 (already introgressed in $\mathrm{BC}_{4} \mathrm{~F}_{2}$ plants). Markers utilized during pyramiding are listed in Table 1. In $\mathrm{F}_{2}$ generations, foreground selection was carried out for three QTL/genes (Gpc-B1, Lr24 and QPhs.dpi.vic.4A.2) and plants homozygous/heterozygous for the three QTL/genes were selected (Fig. 4). Further foreground selection and phenotypic selection was exercised for PHS and four advanced $\mathrm{F}_{5}$ lines were selected, which carried the above three QTL/genes in homozygous conditions and PHS score 2-3 (Fig. 5). These lines were subjected to rust screening and evaluation in yield trials.

\section{Screening of the pyramided lines for rust resistance}

The original cv. Lok1 was only moderately resistant to most of the pathotypes of the three rusts except one pathotype for each (Table 2). However, the MAS-derived parental genotype Lok1 (Gpc-B1+Lr24) used for gene pyramiding, was resistant against three pathotypes (238S119, 78S84, and 47S103) of stripe rust, all the five pathotypes (43232, 77-5, 77-8, 77-9, and 104-2) of leaf rust, and four pathotypes (21A-2, 34-1, 40-1 and 117-6) of stem rust (Table 2). Similar was the resistance pattern of the pyramided lines containing Gpc-B1+Lr24+PHST QTL QPhs.dpivic.4A.2 (Table 2). Therefore, it is obvious that the pyramiding approach used in the present study was successful to produce improved version of $\mathrm{cv}$. Lok1 with improved grain quality and rust resistance. In India, Lr24 (derived from Agropyron elongatum) continues to provide effective resistance, although virulence against $L r 24$ has been reported in South America, North America, and South Africa (Tomar et al. 2014). Therefore, introgression of Lr24 using MAS has also been reported in several earlier studies in India (Samsampour et al. 2009; Revathi et al. 2010; Chhuneja et al. 2011; Kaur et al. 2020). However, for maximum protection, it is recommended that $L r 24$ should be used in combination with other Lr genes (Bolton et al. 2008).

The $L r 24$ gene is also linked with $S r 24$, a stem rust resistance gene effective even against the deadliest race TTKSK (Ug99) (Singh et al. 2006). According to some estimates, the wheat cultivars carrying Lr24/Sr24 occupied a total of about 15 Mha over a period of 20 years (Tomar et al. 2014). In addition to the linked genes $L r 24 / S r 24$, use of other resistance genes, namely Sr31 and Sr36 for stem rust and Lr9, $L r 19$, and $L r 34$ for leaf rust has also been suggested for breeding resistant varieties (Bhardwaj et al. 2019). In India, some of the important genes conferring resistance against the prevalent pathotypes of three rusts include the following: Lr24, Lr37, Lr76 for leaf rust; Sr24, Sr38 for stripe rust; and Yr17, Yr36, Yr70 for yellow rust (Prasad et al. 2019). However in recent years, new virulent races have emerged for some of these genes, of which 77 is the most important race of leaf rust and pathotype 77-9 is the most prevalent. In leaf rust samples of cultivated wheat collected from India and Nepal, pathotype 77-9 was identified in 149 (51.1\%), 77-13 in 20.2\% and $77-5$ in 15.1\% rust samples; Lr24 provided resistance against the pathotype 77-9. Using gene pair $L r 24 / S r 24,18$ wheat varieties for different ecological conditions ranging from moisture stress to irrigated environments, and timely sown to late sown conditions have been released for commercial cultivation in India (Tomar et al. 2014). The presence of this gene pair in our pyramided lines was also confirmed using two stem rust pathotypes (34-1 and 40-1), 
where all the derived pyramided lines were found to be completely resistant to the above two pathotypes (Table 2).

\section{Performance of MAS-derived lines}

The results of ANOVA for two yield trials involving 14 MAS derived lines along with parents [Lok1, Lok1 (Gpc-B1+Lr24), AUS1408, and CN19055] are presented in Table 3. Differences between genotypes were significant for five (TGW, GY, GPC, Fe, and Zn) of the eight traits. Environment effects were also significant for four of the six traits (except TGW and GY). Genotype-by-environment $(g \times e)$ interactions were significant for only three (PH, GY, and GPC) traits suggesting significant effect of environment on the expression of these three traits.

\section{Phenotypic evaluation of the PHS tolerant lines}

\section{(a) Progenies containing only PHST QTL}

The ten (10) improved wheat lines obtained during the present study following MABB involving two crosses (8 from Lok1/AUS1408 and 2 from Lok1/CN19055) and subsequent phenotypic selection for PHST were also evaluated for important agronomic traits. All the 10 derived lines were similar to the recurrent parent cv. Lok1 for four of the eight traits (PH, TPM, GNPS, and GPC), possibly as a result of the 90-96\% recovery of the RPG in these lines following four backcrosses along with background selection (Table 4). However only one line (CCSU-78) showed higher TGW, and only three lines (CCSU-84, -97, and -109) showed higher GY relative to the recipient cv. Lok1. Interestingly, seven lines also had improved grain Fe content (36.5-52.6 ppm) and three lines also had higher grain Zn content (28.7-35.0 ppm) relative to the grain $\mathrm{Fe} / \mathrm{Zn}$ contents of the recurrent parent and each of the two donors (Table 4). Since there is no known relationship between the PHS tolerance and grain mineral contents, we speculate that the observed biofortification may be due to the possible accumulation of complementary genes for high grain Fe and Zn distributed in the recipient parent cv. Lok1 and each of the two donor genotypes (AUS1408 and CN19055). Future studies may be planned to understand the basis of associated biofortification in PHS tolerant lines.

\section{(b) Pyramided progenies containing genes/QTLs for GPC, leaf rust, and PHST}

Four (4) improved Lok1 lines with QPhs.dpivic. 4A.2+Gpc-B1+Lr24 (PHS score=2-3) were also evaluated for five agronomic traits and three grain quality traits. These lines resembled the recipient cv. Lok1 for all the five agronomic traits, but carried higher GPC (12.3\% to 12.5\%), and higher Fe; one line (CCSU-35) also had higher Zn (Table 4). Interestingly, the higher GPC in these lines had no yield penalty despite the known negative association of GPC with grain yield and the effect of genotype, environment and epistatic interactions on GPC (Davies et al. 2006; Brevis and Dubcovsky 2010; Kumar et al. 2011). Wheat lines with high GPC andno yield penalty were also developed earlier through introgression of Gpc-B1 gene following MAS (Kade et al. 2005; Brevis and Dubcovsky 2010; Kumar et al. 2011: Vishwkarma et al. 2016). Using the above Gpc-B1 gene, two commercial bread wheat cv. Lassik and Farnum were also developed earlier 
(Brevis and Dubcovsky 2010; http://variety.wsu

.edu/extensionpubs/Farnumtrifold.pdf,http://uvdavis.edu/files2/57360.pdf; for review see Balyan et al. 2013). The high GPC gene Gpc-B1 has also been exploited in breeding (mostly following MAS) for improvement of grain Fe and Zn associated with GPC in wheat (for reviews see Tabbita et al. 2017; Gupta et al. 2020). These results suggest that while improving PHS tolerance, pyramiding with $G p c-B 1$ can be used not only for protein enrichment but also for biofortification with Fe and $\mathrm{Zn}$ through MAS associated with judicious phenotypic selection.

In summary, a combination of marker-assisted foreground/background and phenotypic selection is a successful strategy for development of improved lines for the trait like PHST. The present study is yet another study of its kind, where MAS was utilized for the improvement of PHS in wheat. The two earlier studies were also conducted in our own laboratory for improvement of wheat cultivars for PHST (Kumar et al. 2010; Tyagi et al. 2014). However in both these earlier studies, we used a major PHS QTL located on $3 \mathrm{~A}$ which was associated with red grain color, which is not preferred by the consumers. During this study, we not only developed PHS tolerant wheat lines with white grains, but also pyramided the PHS tolerance with high GPC and rust resistance. These improved lines should serve as new genetic resources for breeders in future wheat breeding programs.

\section{Declarations}

\section{Acknowledgements}

The work was carried out, when TG held JRF/SRF position under a research project funded by DBT, Government of India. PKG was awarded Hony Scientist position and HSB was awarded Senior Scientist position both from Indian National Science Academy (INSA). Head, Department of Genetics and Plant Breeding, CCS University, Meerut, provided the necessary infrastructure.

\section{Funding}

Funds received from DBT (File No. DBT/PR11695/AGR/02/643/2008), New Delhi, India for carrying out this study.

\section{Authors' contributions}

PKG and HSB designed the experiment. TG carried out phenotyping, data analysis and prepared first draft of the MS. PA, ST, VJ, VG, SK performed the initial breeding work. KK assisted TG in phenotypic data recording. PP carried out rust screening of the pyramided lines. PC provided facilities for KASP assay.

\section{Ethics declarations}




\section{Ethics approval and consent to participate}

Not applicable

Consent for publication

Not applicable

\section{Availability of data and materials}

Not applicable

\section{Competing interests}

The authors declare no competing interests.

\section{References}

Ali A, Cao J, Jiang H et al (2019) Unraveling molecular and genetic studies of wheat (Triticum aestivum L.) resistance against factors causing pre-harvest sprouting. Agronomy 9:117. https://doi.org/10.3390/agronomy9030117

Andreoli C, Bassoi MC, Brunetta D (2006) Genetic control of seed dormancy and pre-harvest sprouting in wheat. Sci Agric 63:564-566. https://doi.org/10.1590/S0103-90162006000600009

Balyan HS, Gupta PK, Kumar S et al (2013) Genetic improvement of grain protein content and other health-related constituents of wheat grain. Plant Breed 132:446-457. https://doi.org/10.1111/pbr.12047

Barrero JM, Cavanagh C, Verbyla KL et al (2015) Transcriptomic analysis of wheat near-isogenic lines identifies PM19-A1 and A2 as candidates for a major dormancy QTL. Genome Biol 16:93. https://doi.org/10.1186/s13059-015-0665-6

Bhardwaj SC, Singh GP, Gangwar OP, Prasad P, Kumar S (2019) Status of wheat rust research and progress in rust management-Indian context. Agronomy 9:892. https://doi.org/10.3390/agronomy9120892

Bansal M, Adamski NM, Toor PI et al (2020) Aegilops umbellulata introgression carrying leaf rust and stripe rust resistance genes $L r 76$ and $Y r 70$ located to $9.47-\mathrm{Mb}$ region on 5DS telomeric end through a combination of chromosome sorting and sequencing. Theor Appl Genet 133:903-915. https://doi.org/10.1007/s00122-019-03514-x

Bokore FE, Knox RE, DePauw RM, et al (2019) Validation of the effects of the Gpc-B1 high grain protein concentration locus from Lillian hard red spring wheat (Triticum aestivum L.) using locus specific markers. Euphytica 215:2. https://doi.org/10.1007/s10681-018-2322-0 
Bolton MD, Kolmer JA, Garvin DF (2008) Wheat leaf rust caused by Puccinia triticina. Mol Plant Pathol 9:563-575. https://doi.org/10.1111/j.1364-3703.2008.00487.x

Brevis JC, Dubcovsky J (2010) Effects of the chromosome region including the locus on wheat grain and protein yield. Crop Sci 50:93. https://doi.org/10.2135/cropsci2009.02.0057

Chhuneja P, Vikal Y, Kaur S et al (2011) Marker assisted pyramiding of leaf rust resistance genes Lr24 and Lr28 in wheat (Triticum aestivum). Indian J Agric Sci 81: 214-218.

Davies J, Berzonsky WA, Leach GD (2006) A comparison of marker-assisted and phenotypic selection for high grain protein content in spring wheat. Euphytica 152:117-134. https://doi.org/10.1007/s10681-0069185-5

De Pauw RM, Mccaig TN (1983) Recombining dormancy and white seed color in a spring wheat cross. Can J Plant Sci 63:581-519. https://doi.org/10.4141/cjps83-074

DePauw RM, Knox RE, Clarke FR et al (2007) Shifting undesirable correlations. Euphytica 157:409-415. https://doi.org/10.1007/s10681-007-9379-5

Distelfeld A, Cakmak I, Peleg Z et al (2007) Multiple QTL-effects of wheat Gpc-B1 locus on grain protein and micronutrient concentrations. Physiol Plant 129:635-643. https://doi.org/10.1111/j.13993054.2006.00841.x

Distelfeld A, Uauy C, Fahima T, Dubcovsky J (2006) Physical map of the wheat high-grain protein content gene $G p c-B 1$ and development of a high-throughput molecular marker. New Phytol 169:753-763. https://doi.org/10.1111/j.1469-8137.2005.01627.x

Divya D, Naik B, Sundaram RM, Laha GS, Bentur JS (2015b) Marker-assisted pyramiding of bacterial blight and gall midge resistance genes in samba Mahsuri and study of their interactions. IJSR 4:22778179.

Ellur RK, Khanna A, Yadav A et al (2016) Improvement of Basmati rice varieties for resistance to blast and bacterial blight diseases using marker assisted backcross breeding. Plant Sci 242:330-341. https://doi.org/10.1016/j.plantsci.2015.08.020

Flintham JE (2000) Different genetic components control coat imposed and embryo-imposed dormancy in wheat. Seed Sci Res 10:43-50. https://doi.org/10.1017/S0960258500000052

Fofana B, Humphreys DG, Rasul G et al (2009) Mapping quantitative trait loci controlling pre-harvest sprouting resistance in a red $\cdot$ white seeded spring wheat cross. Euphytica 165, 509-521. https://doi.org/10.1007/s10681-008-9766-6

Gautam T, Amardeep, Saripalli G et al (2020a) Introgression of a drought insensitive grain yield QTL for improvement of four Indian bread wheat cultivars using marker assisted breeding without background 
selection. J Plant Biochem Biotechnol 30:172-183. https://doi.org/10.1007/s13562-020-00553-0

Gautam T, Dhillon GS, Saripalli G et al (2020b) Marker-assisted pyramiding of genes/QTL for grain quality and rust resistance in wheat (Triticum aestivum L.). Mol

Breed 40:49. https://doi.org/10.1007/s11032-020-01125-9

Groos C, Gay G, Perretant MR et al (2002) Study of the relationship between preharvest sprouting and grain color by quantitative trait loci analysis in a white $\times$ red grain bread-wheat cross. Theor Appl Genet 104:39-47. https://doi.org/10.1007/s001220200004

Gupta PK, Balyan HS, Sharma S, Kumar R (2020) Genetics of yield, abiotic stress tolerance and biofortification in wheat (Triticum aestivum L.). Theor Appl Genet 133:1569-1602. https://doi.org/10.1007/s00122-020-03583-3

Hucl P, Matus-Cadiz M (2002) W98616, a white seeded spring wheat with increased preharvest sprouting. Can J Plant Sci 82:129-131. https://doi.org/10.4141/P01-041

Jamaloddin M, Durga Rani CV, Swathi G et al (2020) Marker Assisted Gene Pyramiding (MAGP) for bacterial blight and blast resistance into mega rice variety "Tellahamsa". PLoS One 15: e0234088. https://doi.org/10.1371/journal.pone.0234088

Joshi AK, Mishra B, Chatrath R, Ortiz Ferrara G, Singh RP (2007) Wheat improvement in India: present status, emerging challenges and future prospects. Euphytica 157:43-446.

https://doi.org/10.1007/s10681-007-9385-7

Kade M, Barneix AJ, Olmos S, Dubcovsky J (2005) Nitrogen uptake and remobilization in tetraploid 'Langdon' durum wheat and a recombinant substitution line with the high grain protein gene Gpc-B1. Plant Breed 124:343-349. https://doi.org/10.1111/j.1439-0523.2005.01110.x

Kaur R, Kaur G, Vikal Y et al (2020) Genetic enhancement of essential amino acids for nutritional enrichment of maize protein quality through marker assisted selection. Physiol Mol Biol Plants 26, 22432254. https://doi.org/10.1007/s12298-020-00897-w

Khan IA, Procunier JD, Humphreys DG et al (2000) Development of PCR-based markers for a high grain protein content gene from Triticum turgidum ssp. transferred to bread wheat. Crop Sci 40:518. https://doi.org/10.2135/cropsci2000.402518x

Klindworth DL, Hareland GA, Elias EM, Faris JD, Chao S, Xu SS (2009) Agronomic and quality characteristics of two new sets of Langdon durum-wild emmer wheat chromosome substitution lines. J Cereal Sci 50:29-35. https://doi.org/10.1016/j.jcs.2009.02.003

Knox RE, Clarke FR, Clarke JM, Fox SL, DePauw RM, Singh AK (2012) Enhancing the identification of genetic loci and transgressive segregants for preharvest sprouting resistance in a durum wheat population. Euphytica 186, 193-206. https://doi.org/10.1007/s10681-011-0557-0 
Kulwal P, Kumar N, Kumar A, Gupta RK, Balyan HS, Gupta PK (2005) Gene networks in hexaploid wheat: interacting quantitative trait loci for grain protein content. Funct Integr Genom 5:254-259. https://doi.org/10.1007/s10142-005-0136-3

Kulwal PL, Kumar N, Gaur A et al (2005) Mapping of a major QTL for pre-harvest sprouting tolerance on chromosome 3A in bread wheat. Theor Appl Genet 111:1052-1059. https://doi.org/10.1007/s00122-0050021-4

Kumar J, Jaiswal V, Kumar A et al (2011) Introgression of a major gene for high grain protein content in some Indian bread wheat cultivars. Field Crop Res 123:226-233.

https://doi.org/10.1016/j.fcr.2011.05.013

Kumar J, Mir RR, Kumar N et al (2010) Marker assisted selection for pre-harvest sprouting tolerance and leaf rust resistance in bread wheat. Plant Breed 129:617-621. https://doi.org/10.1111/j.14390523.2009.01758.x

Li C, Ni P, Francki M, Hunter A et al (2004) Genes controlling seed dormancy and pre-harvest sprouting in a rice-wheat-barley comparison. Func Integr Genomic 4:84-93. https://doi.org/10.1007/s10142-004-01043

Liu S, Cai S, Graybosch R, Chen C, Bai G (2008) Quantitative trait loci for resistance to pre-harvest sprouting in US hard white winter wheat Rio Blanco. Theor Appl Genet 117:691-699. https://doi.org/10.1007/s00122-008-0810-7

Mallick N, Vinod, Sharma JB, Tomar RS, Sivasamy M, Prabhu KV (2015) Marker assisted backcross breeding to transfer multiple rust resistance in wheat. Plant Breed 134:172-177. https://doi.org/10.1111/pbr.12242

Mares D, Mrva K, Cheong J, Williams K, Watson B, Storlie E et al (2005) A QTL located on chromosome 4A associated with dormancy in white and red grained wheats of diverse origin. Theor Appl Genet 111:13571364. https://doi.org/10.1007/s00122-005-0065-5

Mares DJ (1987) Preharvest sprouting tolerance in white-grained wheat. In: Mares DJ (eds) Proceedings of 4th International Symposium. Pre-harvest sprouting in cereals, Westview Press, Boulder, 64.

McIntosh RA, Dubcovsky J, Rogers WJ, Morris C, Xia XC (2017) Catalogue of gene symbols for wheat: 2017 supplement (https://shigen.nig.ac.jp/wheat/ komugi/genes/symbolClassList.jsp).

Mesfin, A, Frohberg RC, Anderson JA (1999) RFLP Markers associated with high grain protein from Triticum turgidum L. var. dicoccoides introgressed into hard red spring wheat. Crop Sci 39:508513. https://doi.org/10.2135/cropsci1999.0011183X003900020035x

Mori M, Uchino N, Chono M, Kato K, Miura H (2005) Mapping QTLs for grain dormancy on wheat chromosome 3A and the group 4 chromosomes, and their combined effect. Theor Appl Genet 110:1315- 
Nörnberg R et al (2015) Tolerance to preharvest sprouting and yield of wheat genotypes from different breeding programs. Pesq Agropec Bras 50, 698-706. http://dx.doi.org/10.1590/S0100204X2015000800008

Ogbonnaya FC, Imtiaz M, Ye G et al (2008) Genetic and QTL analyses of seed dormancy and preharvest sprouting resistance in the wheat germplasm CN10955. Theor Appl Genet 116:891-902. https://doi.org/10.1007/s00122-008-0712-8

Olmos S, Distelfeld A, Chicaiza O, Schlatter AR, Fahima T, Echenique V, Dubcovsky J (2003) Precise mapping of a locus affecting grain protein content in durum wheat. Theor Appl Genet 107:1243-51. https://doi.org/10.1007/s00122-003-1377-y

Prasad P, Gangwar OP, Bharadwaj SC, Kumar S (2019) Monitoring pathotype distribution of Puccinia species on wheat and barley. Mehtaensis 39:5-9. 10.13140/RG.2.2.35390.72007

Rai N, Bellundagi A, Kumar PKC, Thimmappa RK, Rani S, Sinha N et al (2018) Marker-assisted backcross breeding for improvement of drought tolerance in bread wheat (Triticum aestivum $\mathrm{L}$. em Thell). Plant Breed 137:514-526. https://doi.org/10.1111/pbr.12605

Rajjou L, Duval M, Gallardo K et al (2012) Seed germination and vigor. Annu Rev Plant Biol 63:507-533. https://doi.org/10.1146/annurev-arplant-042811-105550

Ramalingam J, Raveendra C, Savitha P et al (2020) Gene pyramiding for achieving enhanced resistance to bacterial blight, blast, and sheath blight diseases in rice. Front Plant Sci 11:591457.

https://doi.org/10.3389/fpls.2020.591457

Randhawa MS, Bains NS, Sohu VS et al (2019) Marker assisted transfer of stripe rust and stem rust resistance genes into four wheat cultivars. Agronomy 9:497. https://doi.org/10.3390/agronomy9090497

Revathi P, Tomar SMS, Vinod, Singh NK (2010) Marker assisted gene pyramiding of leaf rust resistance genes $L r 24, L r 28$ along with stripe rust resistance gene $Y r 15$ in wheat (Triticum aestivum L.). Indian J Genet 70:349-354.

Saghai-Maroof MA, Soliman KM, Jorgensen RA, Allard RW (1984) Ribosomal DNA spacer-length polymorphisms in barley: Mendelian inheritance, chromosomal location and population dynamics. Proc Natl Acad Sci USA 81:8014-8018. https://doi.org/10.1073/pnas.81.24.8014.

Samsampour D, Maleki Zanjani B, Singh A Pallavi JK, Prabhu KV (2009) Marker assisted selection to pyramid seedling resistance gene $L r 24$ and adult plant resistance gene $L r 48$ for leaf rust resistance in wheat. Indian J Genet 69:1-9. 
Sherman JD, Lanning SP, Clark D, Talbert LE (2008) Registration of near-isogenic hard- textured wheat lines differing for presence of a high grain protein gene. J Plant Regist 2:162-164.

https://doi.org/10.3198/jpr2007.09.0528crg

Shorinola O, Balcárková B, Hyles J et al (2017) Haplotype analysis of the pre-harvest sprouting resistance locus $P h s-A 1$ reveals a causal role of TaMKK3-A in global germplasm. Front Plant Sci 8:1555. https://doi.org/10.3389/fpls.2017.01555

Simmonds N (1995) The relation between yield and protein in cereal grain. J Sci Food Agric 67:309-315. https://doi.org/10.1002/jsfa.2740670306

Simsek S, Ohm JB, Lu H et al (2014) Effect of pre-harvest sprouting on physicochemical changes of proteins in wheat. J Sci Food Agric 94:205-12. https://doi.org/10.1002/jsfa.6229

Singh RP, Hodson DP, Jin Y et al (2006) Current status, likely migration and strategies to mitigate the threat to wheat production from race Ug99 (TTKS) of stem rust pathogen. CAB Reviews: Perspectives in Agriculture, Veterinary Science, Nutrition and Natural Resources 1:54.

https://doi.org/10.1079/PAVSNNR20061054

Stakman EC, Stewart DM, LoegeringWQ (1962) Identification of physiologic races of Puccinia graminis var tritici. Agric Res Serv 617:53

Sureshkumar S, Tamilkumar P, Thangavelu AU et al (2014) Marker-assisted introgression of Ipa2 locus responsible for low-phytic acid trait into an elite tropical maize inbred (Zea mays L.). Plant Breed 133:566578. https://doi.org/10.1111/pbr.12185

Tabbita F, Lewis S, Vouilloz JP et al (2013) Effects of the Gpc-B1 locus on high grain protein content introgressed into argentinean wheat germplasm. Plant Breed 132:48-

52. https://doi.org/10.1111/pbr.12011

Tabbita F, Pearce S, Barneix AJ (2017) Breeding for increased grain protein and micronutrient content in wheat: ten years of the Gpc-B1 gene. J Cereal Sci 73:183-191. https://doi.org/10.1016/j.jcs.2017.01.003

Todkar L, Harikrishna, Singh GP, Jain N, Singh PK, Prabhu KV (2020) Introgression of drought tolerance QTLs through marker assisted backcross breeding in wheat (Triticum aestivum L.). Indian J Genet 80:209-212. https://doi.org/10.31742/IJGPB.80.2.12

Tomar SMS, Singh SK, Sivasamy M, Vinod (2014) Wheat rusts in India: resistance breeding and gene deployment - A review. Indian J Genet 74:129-156. https://doi.org/10.5958/0975-6906.2014.00150.3

Torada A, Koike M, Ogawa T, Takenouchi Y, Tadamura K, Wu J (2016) A causal gene for seed dormancy on wheat chromosome 4A encodes a MAP kinase kinase. Current biol 26:782-787.

https://doi.org/10.1016/j.cub.2016.01.063 
Tyagi S, Gupta PK (2012) Meta-analysis of QTLs involved in pre-harvest sprouting tolerance and dormancy in bread wheat. Triticeae Genom Gene 3:9-24. https://doi.org/10.5376/tgg.2012.03.0002

Tyagi S, Mir RR, Kaur H et al (2014) Marker-assisted pyramiding of eight QTLs/genes for seven different traits in common wheat (Triticum aestivum L.). Mol Breed 34:167-175. https://doi.org/10.1007/s11032014-0027-1

Uauy C, Distelfeld A, Fhima T, Blechl A, Dubcovsky J (2006) A NAC gene regulating senescence improves grain protein, zinc, and iron content in wheat. Science 314:1298-1301.

https://doi.org/10.1126/science.1133649

Vishwakarma MK, Arun B, Mishra VK, Yadav PS, Kumar H, Joshi AK (2016) Marker-assisted improvement of grain protein content and grain weight in Indian bread wheat. Euphytica 208:313-321. https://doi.org/10.1007/s10681-015-1598-6

Vishwakarma MK, Mishra VK, Gupta PK, Yadav PS, Kumar H, Joshi AK (2014) Introgression of the high grain protein gene $G p c-B 1$ in an elite wheat variety of Indo-Gangetic Plains through marker assisted backcross breeding. Curr Plant Biol 7:292-300. https://doi.org/10.1016/j.cpb.2014.09.003

Yadav PS, Mishra VK, Arun B, Chand R, Vishwakarma MK, Vasistha NK et al (2015) Enhanced resistance in wheat against stem rust achieved by marker assisted backcrossing involving three independent $\mathrm{Sr}$ genes. Curr Plant Biol 2:25-33. https://doi.org/10.1016/j.cpb.2015.05.001

Zhou Y, Tang H, Cheng MP et al (2018) Genome-wide association study for pre-harvest sprouting resistance in a large germplasm collection of Chinese wheat landraces. Front Plant Sci 8:401. https://doi.org/10.3389/fpls.2017.00401

\section{Tables}

Table 1 List of QTL/genes, chromosomal location, linked molecular markers and the size of PCR product in parental lines. 


\begin{tabular}{|llll|}
\hline Trait & QTL/genes (chromosome) & Marker (product size bp) & Reference \\
\hline SD & Phs-A1 (4A) & Xbarc170 (197) & Mares et al. 2005 \\
\hline SD & Phs-A1 (4A) & Xgwm397(190) & Mares et al. 2005 \\
\hline SD/PHST & QPhs.dpi.vic.4A.2 & Xgwm637(160) & Ogbonnaya et al. 2008 \\
\hline SD/PHST & QPhs.dpi.vic.4A.2 & Xgwm894 (180) & Ogbonnaya et al. 2008 \\
\hline SD & TaMKK3-A(4A) & KASP assay (C/A) & Shorinola et al. 2017 \\
\hline GPC & Gpc-B1/Yr36(6B) & Xucw108 (220) & Uayu et al. 2006 \\
\hline Leaf rust & Lr24(3D) & SCS73719 $(719)$ & Prabhu et al. 2004 \\
\hline
\end{tabular}

SD, seed dormancy; PHST, pre-harvest sprouting tolerance; GPC, grain protein content

Table 2 A summary of the results of screening of MAS-derived pyramided lines, a MAS-derived parental genotype, and a check cv. Lok1 against different pathotypes of the three rusts under glasshouse conditions. 


\begin{tabular}{|c|c|c|c|c|c|c|}
\hline Rust & Pathotype & Distribution in India & Status & Lok1 & $\begin{array}{l}\text { Lok1 } \\
\text { (Gpc- } \\
B 1+L r 24)\end{array}$ & $\begin{array}{l}\text { Pyramided } \\
\text { lines }\end{array}$ \\
\hline \multirow{4}{*}{$\begin{array}{l}\text { Stripe } \\
\text { rust }\end{array}$} & $238 S 119$ & \multirow{4}{*}{ NHZ and NWPZ } & Predominant & $3^{+}$ & 0 & 0 \\
\hline & $78 S 84$ & & Predominant & 0 & 0 & 0 \\
\hline & $47 S 103$ & & High virulence & $3^{+}$ & ; & 0 \\
\hline & $110 S 119$ & & Predominant & $3^{+}$ & $3^{+}$ & $3^{+}$ \\
\hline \multirow{5}{*}{$\begin{array}{l}\text { Leaf } \\
\text { rust }\end{array}$} & $12-5$ & \multirow{5}{*}{$\begin{array}{l}\text { Uniform } \\
\text { distribution in all } \\
\text { the zones }\end{array}$} & Predominant & - & ; & 0 \\
\hline & $77-5$ & & Predominant & $3^{+}$ & ; & 0 \\
\hline & $77-8$ & & Predominant & $3^{+}$ & ; & 0 \\
\hline & $77-9$ & & Predominant & 0 & 0 & 0 \\
\hline & $104-2$ & & High virulence & $3^{+}$ & ; & 0 \\
\hline \multirow{7}{*}{$\begin{array}{l}\text { Stem } \\
\text { rust }\end{array}$} & 11 & $\mathrm{PZ}$ & Predominant & $2^{-}$ & $2^{-}$ & $2^{-}$ \\
\hline & $21 \mathrm{~A}-2$ & NHZ and NWPZ & Predominant & ; & ; & ; \\
\hline & $34-1$ & $\begin{array}{l}\text { Restricted to Leh } \\
\text { Ladakh area }\end{array}$ & $\begin{array}{l}\text { For checking } \\
\text { presence of } \\
\text { Lr24/Sr24 }\end{array}$ & - & 0 & 0 \\
\hline & $40 \mathrm{~A}$ & $\mathrm{CZ}, \mathrm{PZ}$ and $\mathrm{SHZ}$ & Predominant & $3^{+}$ & $2^{-}$ & $2^{-}$ \\
\hline & $40-1$ & $\mathrm{CZ}, \mathrm{PZ}$ and $\mathrm{SHZ}$ & $\begin{array}{l}\text { For checking } \\
\text { presence of } \\
\text { Lr24/Sr24 }\end{array}$ & $2^{-}$ & ; & ; \\
\hline & $117-6$ & $\mathrm{CZ}, \mathrm{PZ}$ and $\mathrm{SHZ}$ & High virulence & 2 & ; & ; \\
\hline & 122 & $\mathrm{CZ}, \mathrm{PZ}$ and $\mathrm{SHZ}$ & High virulence & $2^{-}$ & $2^{-}$ & $2^{-}$ \\
\hline
\end{tabular}

ITs ; and 0 ; indicating resistant; $2^{-}, 2^{+}$indicating moderately resistant; 3 indicating moderately susceptible; and $3+$ indicating susceptible; plus (+), and minus (-) signs indicate variation within a given infection type.

Table 3 Analysis of variance (ANOVA) for seven traits involving parental genotypes and MAS-derived lines based on data collected from trials over two years. 


\begin{tabular}{|c|c|c|c|c|c|}
\hline Source of Variation & Environments & Replications & Genotypes & $G * E$ & Error \\
\hline DF & 1 & 1 & 17 & 17 & 35 \\
\hline \multicolumn{6}{|l|}{ Traits } \\
\hline $\mathrm{PH}$ & $33.3^{\star *}$ & 2.3 & 1098.7 & $2.1^{\star \star}$ & 0.7 \\
\hline TPM & $6469.5^{\star *}$ & 5451.4 & 636.2 & 301.2 & 406.1 \\
\hline GNPS & $31920.0 *$ & 187.0 & 1555.0 & 557.0 & 1180.0 \\
\hline TGW & 5.0 & 2.7 & $82.4^{\star}$ & 41.7 & 39.4 \\
\hline GY & 0.3 & 0.0 & $0.8^{* *}$ & $0.7 * \star$ & 0.3 \\
\hline GPC & $2.2^{\star \star}$ & 0.3 & $5.8^{\star \star}$ & $1.3^{\star \star}$ & 0.2 \\
\hline $\mathrm{Fe}$ (ppm) & - & 2.5 & $199.7^{\star *}$ & - & 6.4 \\
\hline Zn (ppm) & - & 11.3 & $67.3 * \star$ & - & 17.5 \\
\hline
\end{tabular}

*Significantly higher at $5 \%$ level of significance; ** significantly higher at $1 \%$ level of significance; $G$, genotype; $\mathrm{E}$, environment; $\mathrm{PH}$, plant height; TPM, tillers per meter; GNPS, grain per spike; TGW, 1000-grain weight; GY, grain yield, GPC, grain protein content, Fe, iron; Zn, zinc

Table 4 Mean values for seven different traits of the 10 MABB derived PHS tolerant and 4 pyramided lines and their parental genotypes based on pooled data over two years. 


\begin{tabular}{|c|c|c|c|c|c|c|c|c|}
\hline Genotypes & $\begin{array}{l}\mathrm{PH} \\
(\mathrm{cm})\end{array}$ & TPM & GNPS & $\begin{array}{l}\text { TGW } \\
\text { (g) }\end{array}$ & $\begin{array}{l}\text { GY } \\
\text { (t/ha) }\end{array}$ & $\begin{array}{l}\text { GPC } \\
(\%)\end{array}$ & $\begin{array}{l}\mathrm{Fe} \\
(\mathrm{ppm})\end{array}$ & $\begin{array}{l}\mathrm{Zn} \\
(\mathrm{ppm})\end{array}$ \\
\hline \multicolumn{9}{|l|}{ Parents } \\
\hline Lok1 & 96.0 & 104.0 & 160.0 & 57.0 & 3.2 & 9.9 & 25.6 & 18.5 \\
\hline Lok1 (Gpc-B1+Lr24) & 95.8 & 111.5 & 165.0 & 57.6 & 3.1 & 12.4 & 29.5 & 19.9 \\
\hline AUS1408 & 151.0 & 113.7 & 144.5 & 50.9 & 3.1 & 11.7 & 24.4 & 19.3 \\
\hline CN19055 & 142.0 & 128.0 & 114.5 & 52.0 & 2.5 & 12.1 & 29.9 & 23.4 \\
\hline \multicolumn{9}{|l|}{ MAS derived PHST lines } \\
\hline CCSU-55 & 96.3 & 83.9 & 162.7 & 62.5 & 3.7 & 10.0 & 32.9 & 17.4 \\
\hline CCSU-63 & 95.8 & 94.9 & 182.2 & 60.2 & 3.8 & 9.6 & $50.3^{\star}$ & $35.0 *$ \\
\hline CCSU-64 & 94.8 & 104.9 & 179.5 & 59.8 & 3.9 & 10.3 & $52.6^{\star}$ & 27.2 \\
\hline CCSU-68 & 95.3 & 86.4 & 157.2 & 64.9 & 3.7 & 9.7 & $31.4^{\star}$ & 16.7 \\
\hline CCSU-73 & 95.0 & 82.1 & 166.7 & 60.7 & 3.7 & 9.5 & 24.2 & 15.3 \\
\hline cCSU-77 & 94.7 & 104.6 & 177.2 & 64.9 & 3.4 & 9.5 & $38.3^{*}$ & 23.4 \\
\hline CCSU-78 & 95.3 & 98.1 & 160.2 & $66.6^{*}$ & 3.8 & 10.2 & 21.7 & 14.5 \\
\hline CCSU-84 & 95.3 & 80.7 & 199.5 & 57.7 & $4.0 *$ & 10.2 & $45.0 *$ & $28.7 *$ \\
\hline CCSU-97 & 95.0 & 94.1 & 152.0 & 57.1 & $4.3^{*}$ & 10.6 & $36.5^{\star}$ & 25.7 \\
\hline CCSU-109 & 97.0 & 93.6 & 132.7 & 57.9 & $4.0^{*}$ & 9.9 & $46.6^{\star}$ & $30.9 *$ \\
\hline \multicolumn{9}{|l|}{ Pyramided lines } \\
\hline $\begin{array}{l}\text { CCSU-25 (Gpc-B1+Lr24+ } \\
\text { QPhs.dpivic. } 4 A .2)\end{array}$ & 95.8 & 106.7 & 146.2 & 62.1 & 3.8 & $12.5^{\star}$ & $31.1^{\star}$ & 16.7 \\
\hline $\begin{array}{l}\text { CCSU-31 (Gpc-B1+Lr24+ } \\
\text { QPhs.dpivic.4A.2) }\end{array}$ & 96.3 & 85.4 & 176.7 & 56.0 & 3.2 & $12.5^{\star}$ & $35.6^{*}$ & 20.8 \\
\hline $\begin{array}{l}\text { CCSU-34 (Gpc-B1+Lr24+ } \\
\text { QPhs.dpivic. } 4 A .2)\end{array}$ & 95.5 & 94.7 & 155.0 & 52.4 & 3.2 & $12.3^{*}$ & $31.8^{\star}$ & 19.9 \\
\hline $\begin{array}{l}\text { CCSU-35 (Gpc-B1+Lr24+ } \\
\text { QPhs.dpivic. } 4 A .2)\end{array}$ & 97.0 & 89.4 & 174.7 & 54.9 & 3.5 & $12.3^{*}$ & $51.4^{\star}$ & $27.3^{*}$ \\
\hline LSD & 1.2 & 28.9 & 49.3 & 9.0 & 0.7 & 0.7 & 5.3 & 8.8 \\
\hline
\end{tabular}

*Significantly higher at $5 \%$ level of significance; PH, plant height; TPM, tillers per meter; GNPS, grain per spike; TGW, 1000-grain weight; GY, grain yield, GPC, grain protein content, Fe, iron; Zn, zinc; LSD, least significant difference 


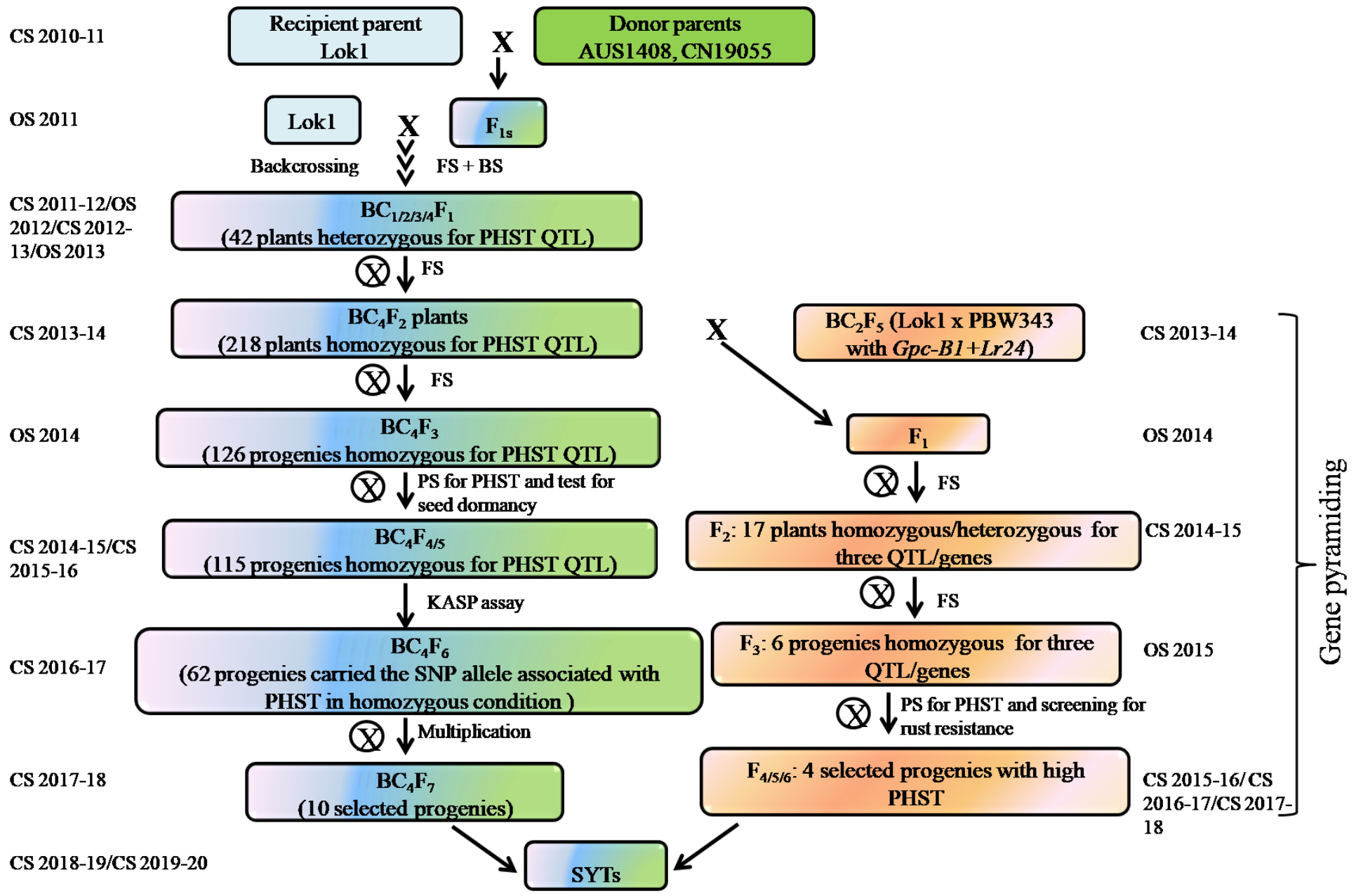

\section{Figure 1}

Marker assisted breeding scheme used in the present study for introgression of a PHST QTL (involving two different donors, AUS1408 and CN19055) and pyramiding QTL/genes for PHST, GPC and leaf rust resistance: $\mathrm{PHST}=$ pre-harvest sprouting tolerances; $\mathrm{GPC}=$ grain protein content; $\mathrm{CS}=$ crop season; $\mathrm{OS}=$ off season; FS = foreground selection; BS = background selection; $\mathrm{PS}$ = phenotypic selection; $\mathrm{SYT}=$ station yield trial. 

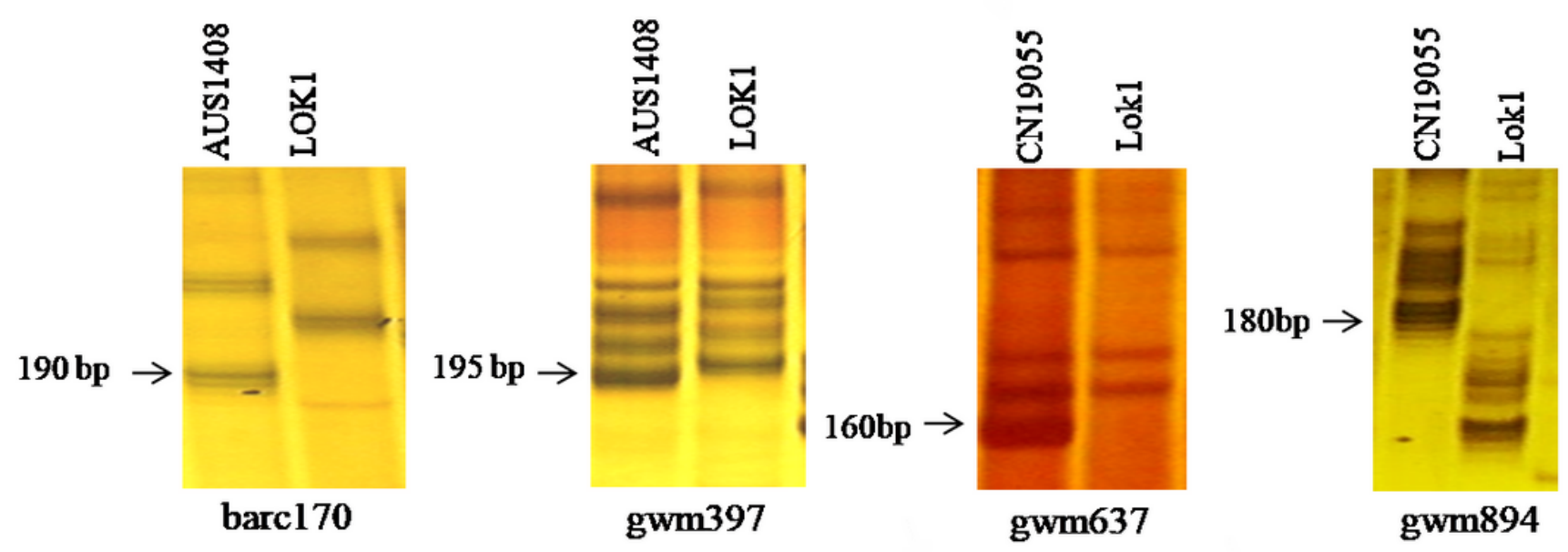

Figure 2

Amplification profiles of markers associated with PHST QTL in parental lines. 


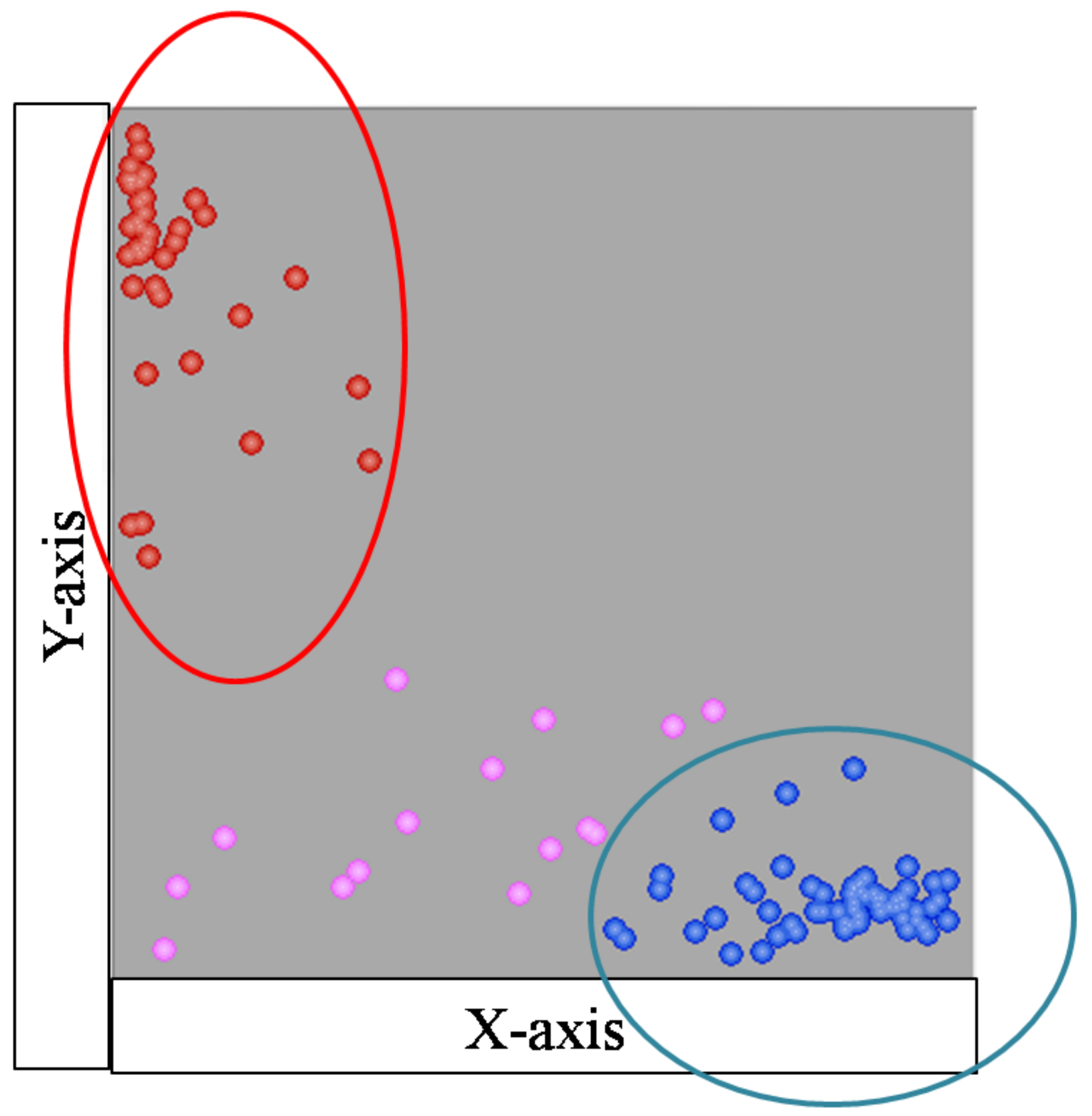

Figure 3

KlusterCaller output view of segregation of KASP marker associated with PHST gene TaMKK3-A in BC4F6 population. Co-dominant KASP marker segregating for FAM tailed TaMKK3-A-snp1-res_FAM (blue colour) and VIC tailed TaMKK3-A-snpA1-sus_VIC (red colour) alleles on X-and Y-axes of the plot, respectively, and heterozygous individuals on mid-axis (pink colour). 


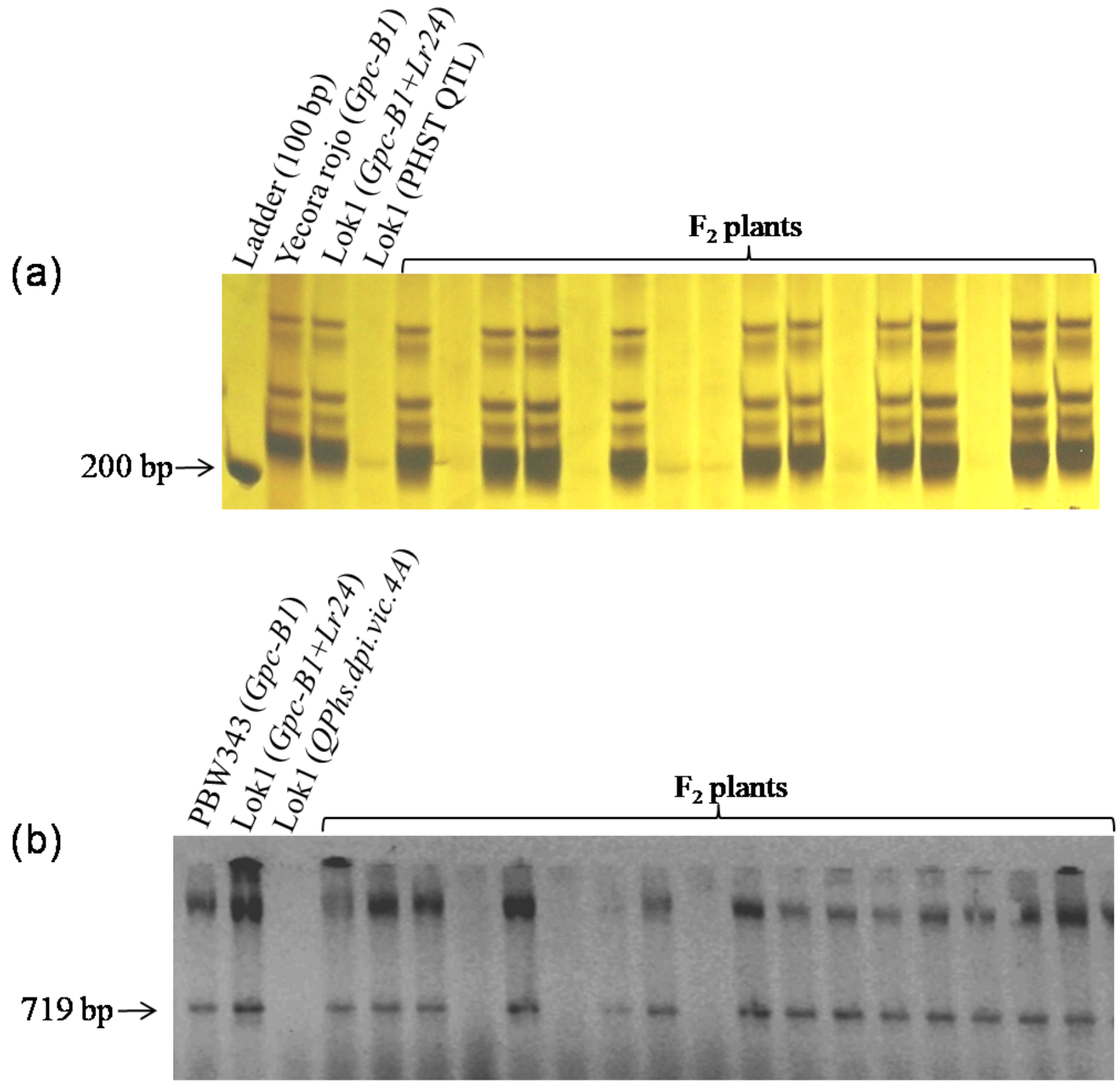

Figure 4

Amplification profiles of markers associated with (a) Gpc-B1 and (b) Lr24 in parental lines and F2 plants. 
(a)

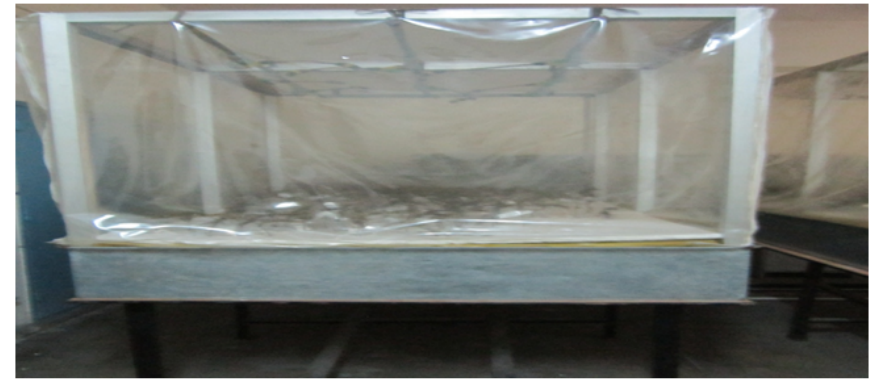

(c)

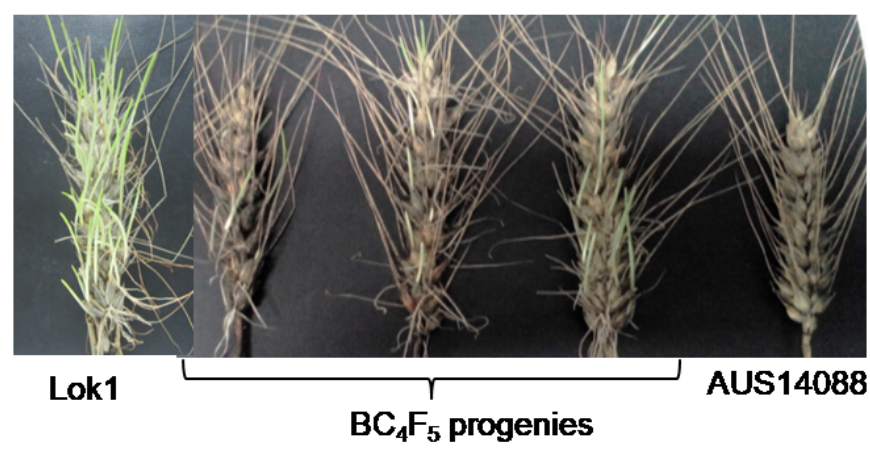

(b)

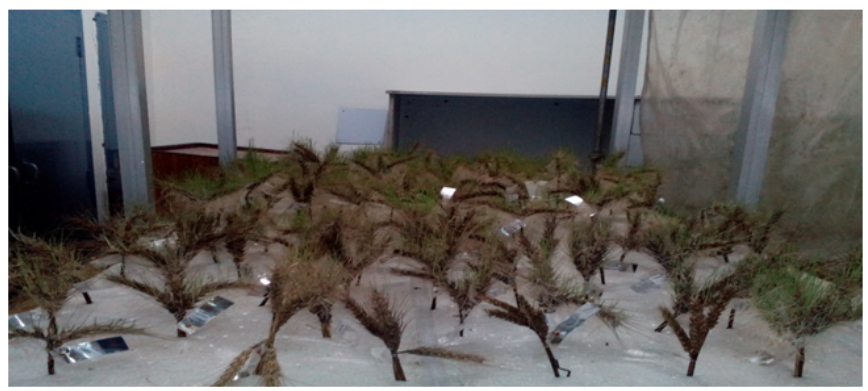

(d)

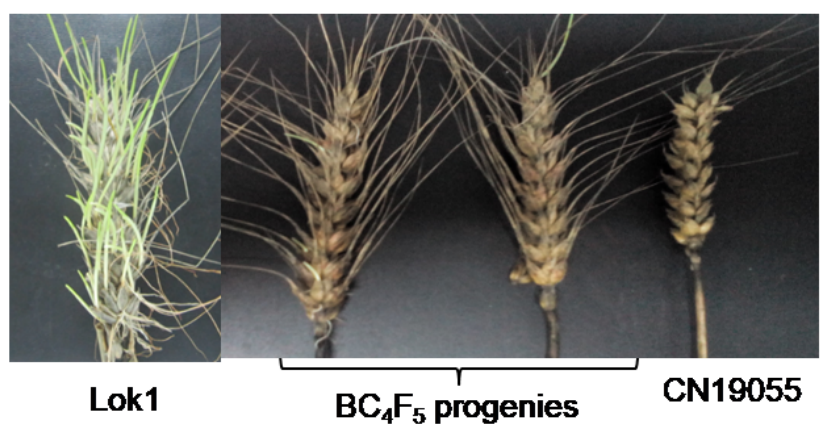

(e)

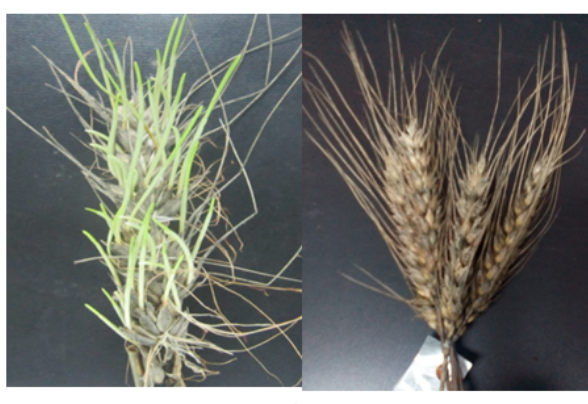

Lok1

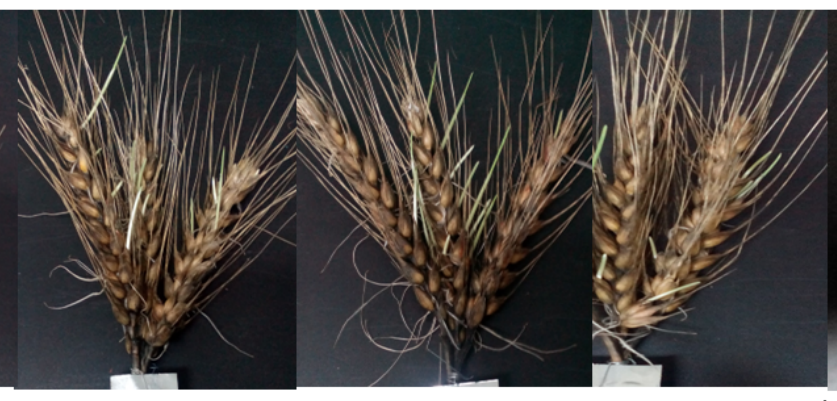

$F_{5}$ progenies

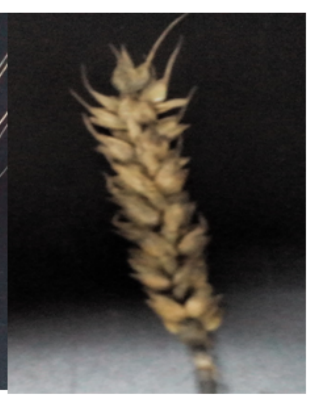

CN19055

\section{Figure 5}

Screening for PHS under laboratory conditions: (a) Rain simulating chambers designed for the screening of PHS of wheat genotypes, (b) Spikes arranged in a rain simulating chamber for screening of PHS, (c) and (d) Phenotypes of spikes following testing of PHS of the two PHS tolerant donor genotypes (AUS1408 and CN19055), a PHS sensitive recipient genotype (Lok1) and the BC4F5 progenies. (e) Phenotypes of spikes following testing of PHS of the PHS tolerant donor genotype (CN19055) and PHS sensitive recipient genotype (Lok1) and four PHS tolerant QTL/gene pyramided F5 lines. 